\title{
Fatty Acids in Heterocyclic Synthesis: Part XIX Synthesis of Some Isoxazole, Pyrazole, Pyrimidine and Pyridine and Their Surface, Anticancer and Antioxidant Activities
}

\author{
Abdelmotaal Abdelmajeid*, Mahasen Saad Amine*, Reda Ali Hassan \\ Chemistry Department, Faculty of Science, Benha University, Benha, Egypt \\ Email address: \\ a.elshiekh@fsc.bu.edu.eg (A. Abdelmajeid), mahsen_amine@yahoo.com (M. S. Amine), reda.ali201080@yahoo.com (R. A. Hassan) \\ ${ }^{*}$ Corresponding author
}

To cite this article:

Abdelmotaal Abdelmajeid, Mahasen Saad Amine, Reda Ali Hassan. Fatty Acids in Heterocyclic Synthesis: Part XIX Synthesis of Some Isoxazole, Pyrazole, Pyrimidine and Pyridine and Their Surface, Anticancer and Antioxidant Activities. American Journal of Heterocyclic Chemistry. Vol. 4, No. 2, 2018, pp. 30-41. doi: 10.11648/j.ajhc.20180402.11

Received: March 12, 2018; Accepted: April 11, 2018; Published: July 3, 2018

\begin{abstract}
Acryloylphenylstearamide (2) was utilized as a starting material for synthesis the titled compounds via one-pot synthesis. Compound (2) was reacted with hydroxylamine hydrochloride in pyridine and produced isooxazole (3), and with thiosemicarbazide in pyridine and/or hydrazine-hydrate in ethanol afforded pyrazoles (4), and (5), while the reaction of (2) with urea and/ or thiourea in an alcoholic solution of sodium ethoxide gave pyrimidinone (6) and pyrimidinedione (7). Also, reaction of (2) with acetylacetone and/or ethyl acetoacetate in acetic acid andammonium acetateafforded Pyridine derivatives (8), and (9) respectively. Addition of different amounts of propylene oxide (3, 5, 7 moles) to the synthesized compounds produced nonionic surfactants $(2-9 \mathrm{a}-\mathrm{c})$. The physiochemical and surface active properties of the prepared surfactant as surface and interfacial tension, cloud point, wetting time, emulsion stability, foam height, CMC, resistance to hydrolysis and their biodegradability were investigated. Also, the surface parameters as effectiveness ( $\pi \mathrm{CMC}$ ), efficiency (PC20), maximum surface excess ( $\Gamma \max )$ and $(A \min )$ were evaluated.
\end{abstract}

Keywords: Stearoyl Chloride, P-Aminoacetophenone, Nonionic Surfactant, Propylene Oxide

\section{Introduction}

The anticancer activity of the synthesized compounds were reported, and it was found that pyrazoles 4 and 5 are highlyeffect against examined human tumor cells. Also, the antioxidant activity of those compounds was reported.

In the recent year a great effort of the researcher is interested in cancer, as it is one of the leading causes of death. Search for novel and selective anticancer agents has attracted considerable attention because of the problem associated with currently available anticancer drug as an unfavorable side effect such reduced bioactivity.

In continuation of our program aiming to synthesize a new heterocyclic compounds having potential chemotherapeutic activities and surface properties from fatty acids $[1-8]$.

\section{Result and Discussion}

Herein, we report the synthesis of some new isoxazole, pyrazole, pyrimidine and pyridine with potential anticancer activity, which having surface active properties. Isoxazoles are unique in their chemical behavior and have attracted biological and pharmacological properties [9-13].

Starting from stearic acid that was converted to the corresponding stearoyl chloride using thionyl chloride as chlorinating agent. The reaction of stearoyl chloride and paminoacetophenone afforded $\mathrm{N}$-(4-acetylphenyl) stearamide (1) which converted to $\mathrm{N}$-(4-(3-phenylacryloyl) phenyl) stearamide (2) via fusion with benzaldehyde (general method) outlined in "figure 6" and "figure 7".

The target compound isoxazole N-(4-(3-phenyl-2,3dihydroisoxazole-5-yl) $\mathrm{N}$ phenyl) stearamide (3) was obtained on refluxing compound (2) with hydroxylamine 
hydrochloride in pyridine as a base.

The structure of compound (3) was confirmed on the bases of IR, Mass, ${ }^{1} \mathrm{H}-\mathrm{NMR}$ spectroscopic analysis as well as elemental analytical data. IR showed $v \mathrm{NH}$ at $3342 \mathrm{~cm}^{-1}$, $v \mathrm{C}=\mathrm{O} 1675 \mathrm{~cm}^{-1},{ }^{1} \mathrm{HNMR}$ showed $\delta 12.0(\mathrm{~s}, 1 \mathrm{H}$, exchangeable $\mathrm{NH})$ besides, the aliphatic chain and aromatic protons. The fragmentation ofMass spectrum supported the proposed structure c.f. "figure 1".

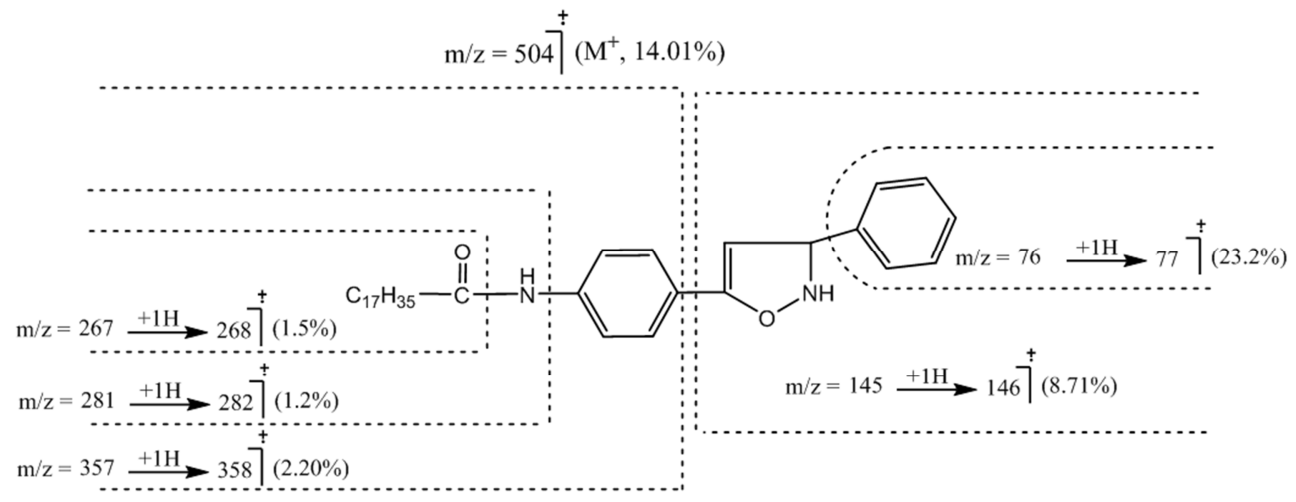

Figure 1. Mass fragmentation of compound 3.

Pyrazole derivatives were designed and synthesized as potential protein kinase inhibitions [14-16]. In the view to develop a specific antitumor therapies, Aminopyrazoles emerged as a powerful pharmacophore scaffold and they have been extensively used to design various kinase inhibitor. Large-scale research aimed for developing specific synthetic routes to these compounds. Thiourea and acyl group are used for their ability to form hydrogen bonds with the kinase. Also the thioamide is an isoester of amide and has the advantage of being a better hydrogen bond donor and sulfur is superior donor for $\pi-\pi^{*}$ interaction such bond being very importantin the ligand-kinase interaction.

Thus, reaction of acryloyl steraamid (2) with thiosemicarbazide in refluxing pyridine producedN-(4-(1carbamothioyl-5-phenyl-4, 5-dihydro-1H-pyrazol-3-yl) phenyl) stearamide (4). The IR, ${ }^{1} \mathrm{H}-\mathrm{NMR}$ and fragmentation pattern of mass spectrum supported the proposed structure c.f. "figure 2 ".

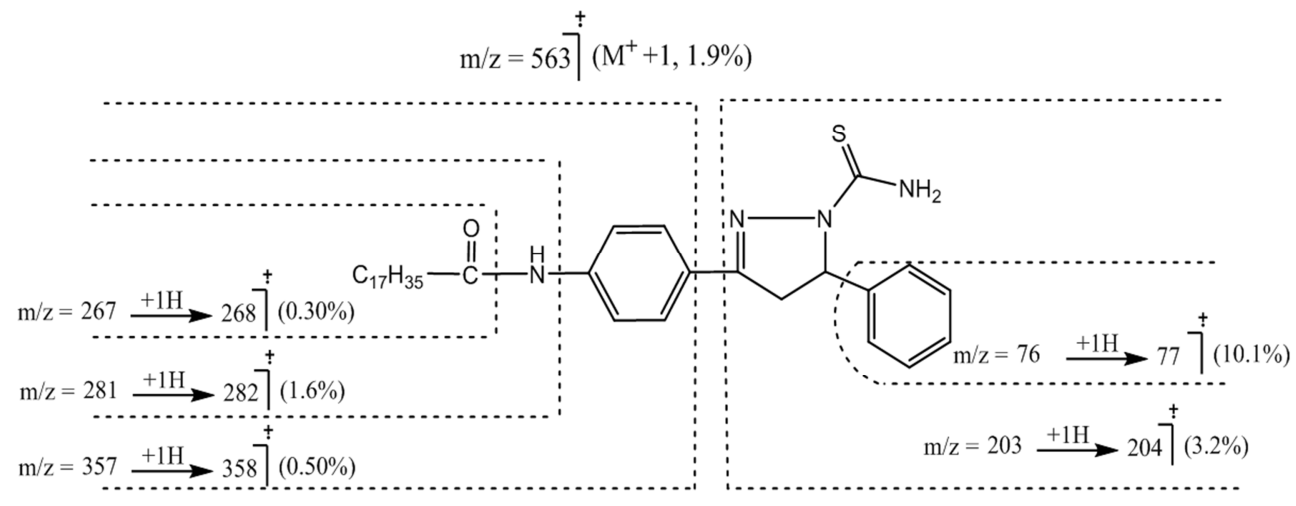

Figure 2. Mass fragmentation of compound 4.

Hydrazine hydrate react with acryloyl stearamide (2) in boiling ethanol and produced $N$-(4-(5-phenyl-4, 5-dihydro- $1 \mathrm{H}-$ pyrazol-3-yl) phenyl) stearamide (5). Which confirmed from the spectral data and the mass fragmentation pattern c.f. "figure $3 "$.

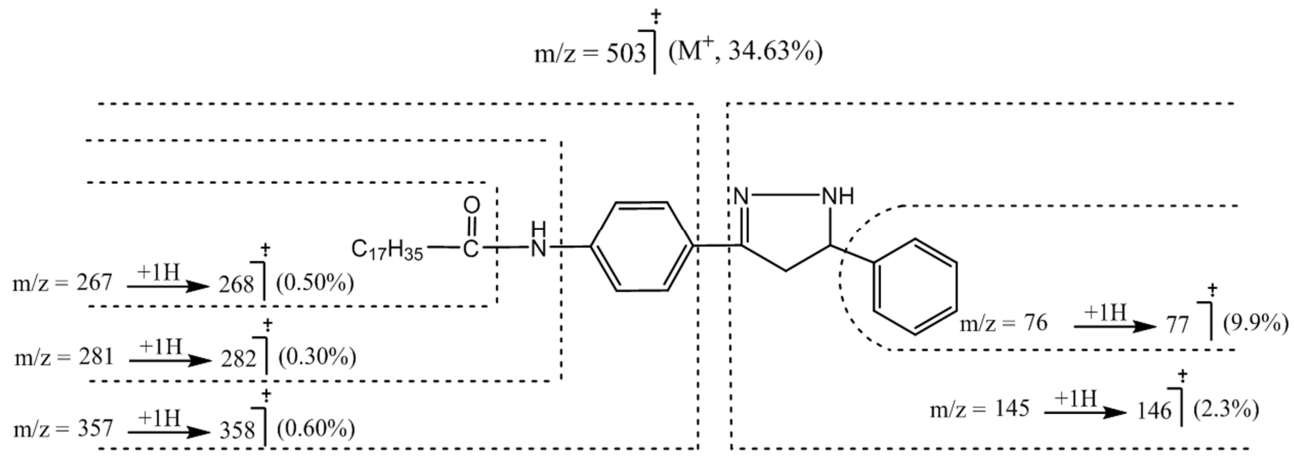

Figure 3. Mass fragmentation of compound 5. 
Pyrimidine compounds are also used as hypnotic drugs for the nervous system, calcium-sensing receptor, antagonize has the human A2A adenosine receptor[17-19]. Owing to the importance, herein, wesynthesziseN-(4-(2-hydroxy-6-phenyl pyrimidine-4-yl) phenyl) stearamide (6) and N-(4-(2mercapto-6-phenyl pyrimidine-4-yl) phenyl) stearamide (7) by refluxing urea and/or thiourea with acryloyl stearamide in alcoholic solution of sodium ethoxide, IR showed $v(\mathrm{OH})$ at 3417, $v(\mathrm{NH})$ at 3318 beside the other bonds of the compound. ${ }^{1} \mathrm{H}-\mathrm{NMR}$ showed $\delta$, s at 10.2, 10.25exchangable for the $\mathrm{NH}, \mathrm{OH}$, while, IR of compound (7) showed $v(\mathrm{SH})$ at $1177 \mathrm{~cm}^{-1}$. The ${ }^{1} \mathrm{H}-\mathrm{NMR}$ and fragmentation pattern of the mass spectra supported the predicted structures c.f. "figure 4 "and "figure 5".

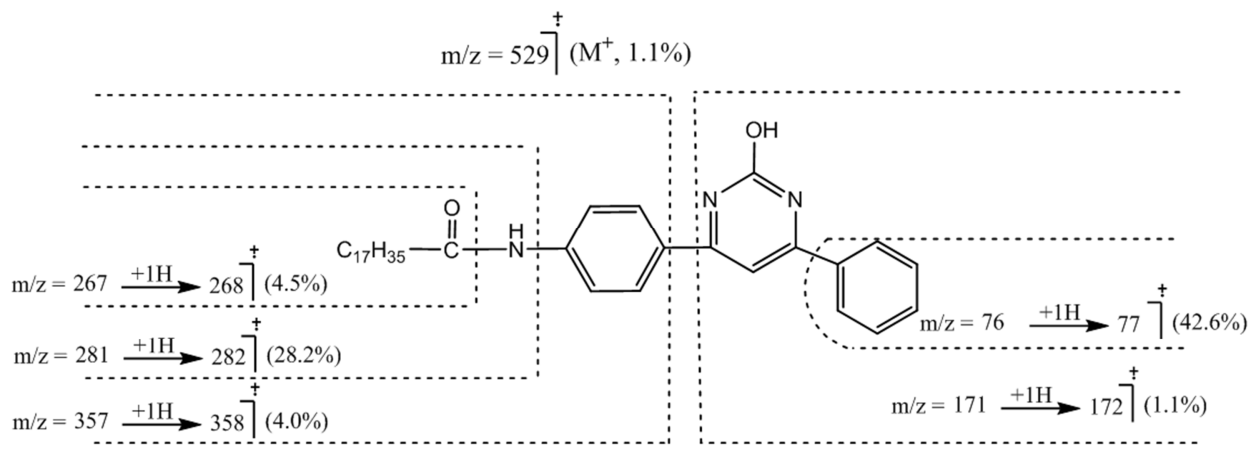

Figure 4. Mass fragmentation of compound 6.

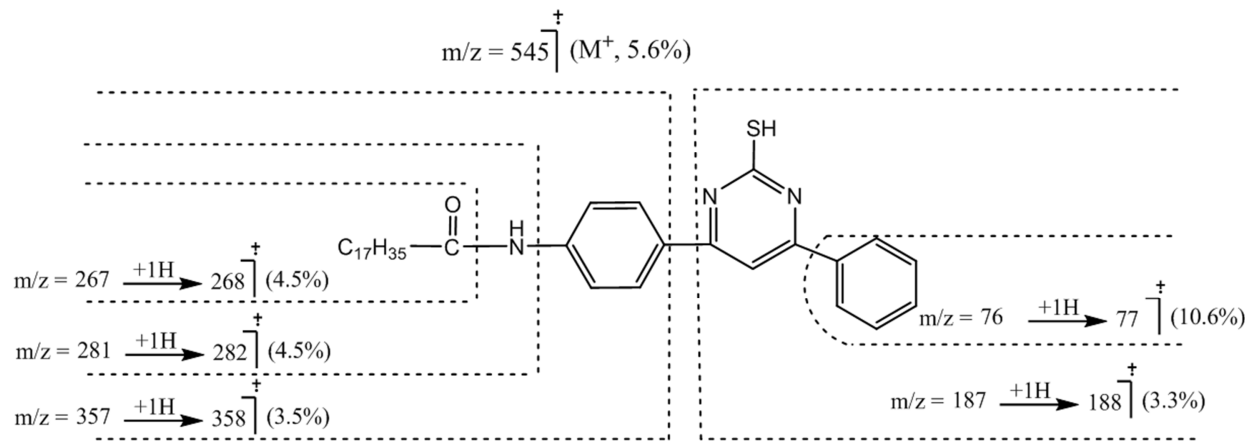

Figure 5. Mass fragmentation of compound 7

Pyridine well known by its effectiveness as sulfa pyridine drug against bacterial and viral infection, antihistamic, and herbicides [20-21].

When acetylacetone and/or ethyl acetoacetate was refluxed with acryloyl stearamide (2) in presence of ammonium acetate in acetic acid producedN-(4-(6-acetylpyridine-2- yl) phenyl) stearamide (8), and N-(4-(6-propionylpyridin-2- yl) phenyl) stearamide (9), respectively, IR of (8) showed $v$ $(\mathrm{NH})$ at $3357, v \mathrm{C}=\mathrm{O}$ 's at $1699,1600 \mathrm{~cm}^{-1}$, and its ${ }^{1} \mathrm{H}-\mathrm{NMR}$ and fragmentation pattern of the mass spectra supported the predicted structure. On the other side, IR spectrum of (9) showed $v(\mathrm{NH})$ at $3415, v \mathrm{C}=\mathrm{O}$ 's at $1700,1600 \mathrm{~cm}^{-1} .{ }^{1} \mathrm{H}-\mathrm{NMR}$ showed $\delta 10.2(\mathrm{~s}, 1 \mathrm{H}, \mathrm{NH})$ and the mass spectra showed $[\mathrm{M}+]$ at 492 .

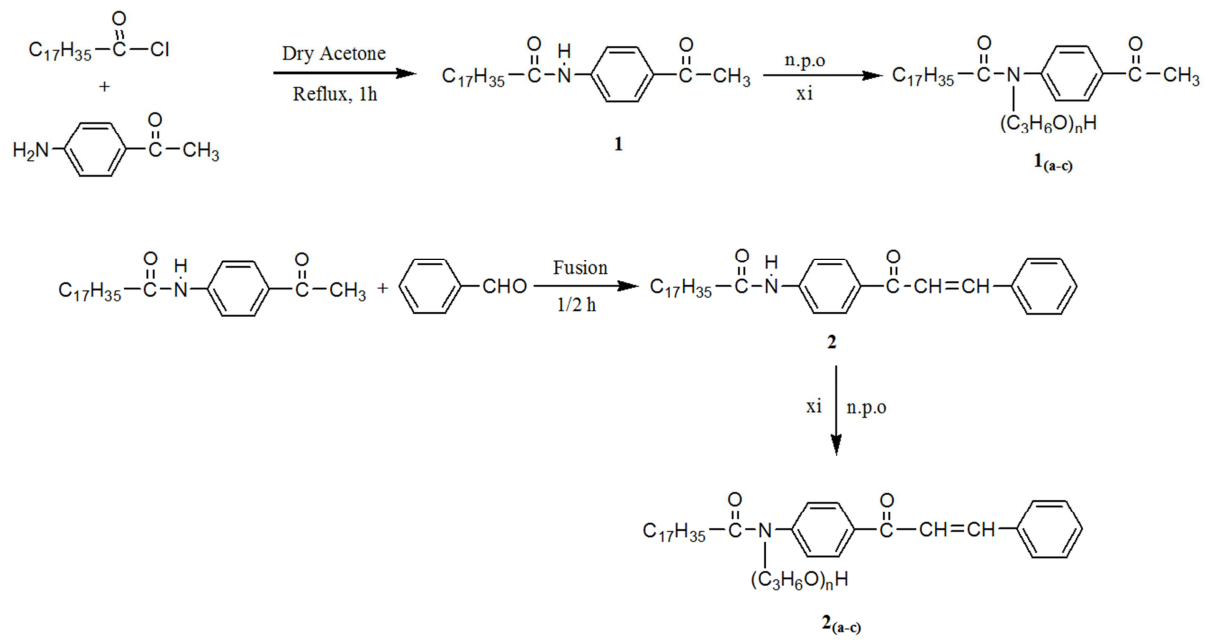

Figure 6. Synthetic routes of compounds 1,2 and surfactants $\left(1_{a-c}, 2_{a-c}\right)$. 


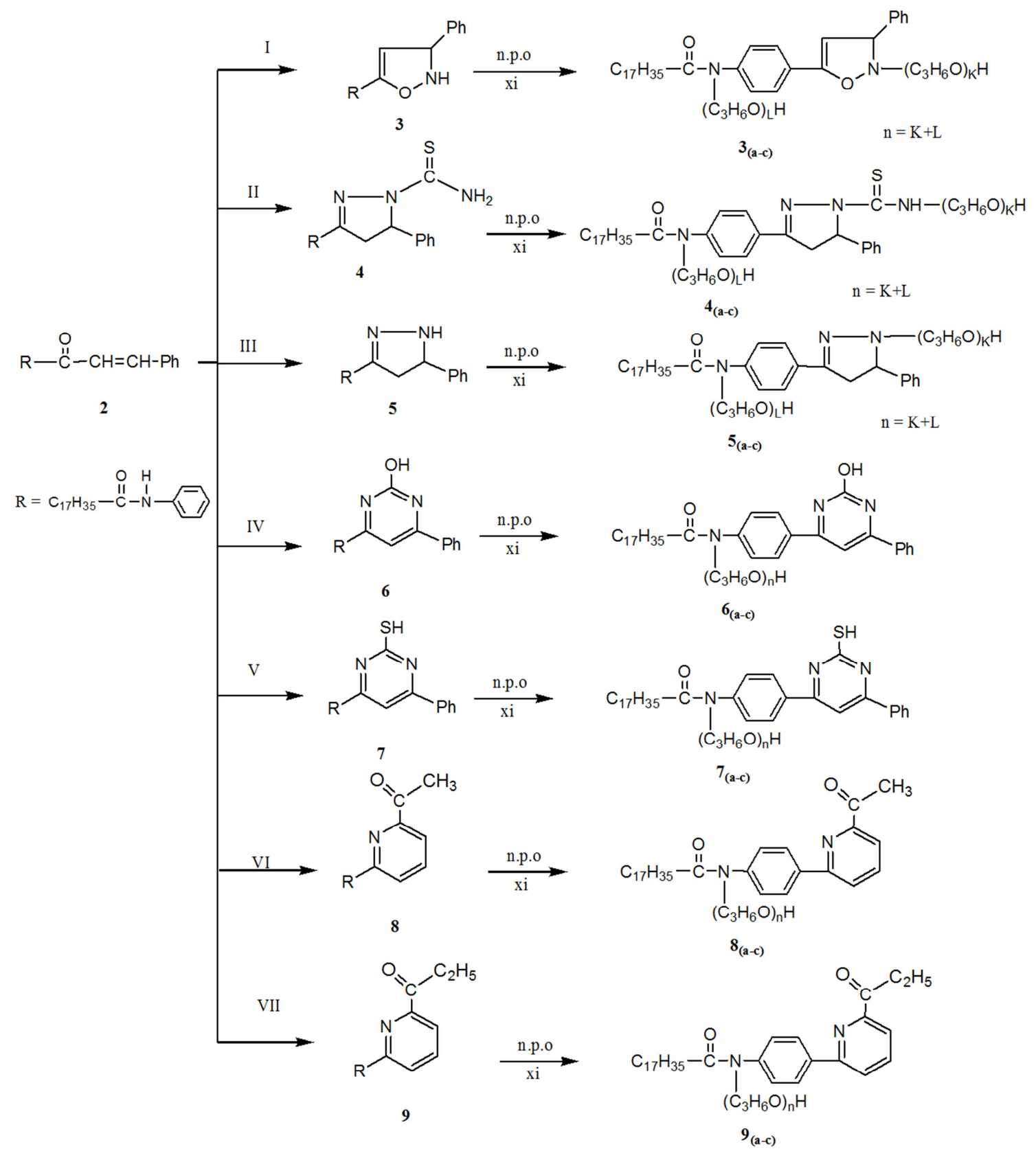

Figure 7. Synthetic routes of compounds 3-9 and surfactants $\left(3_{a-c},-9_{a-c}\right)$.

$\mathrm{NH}_{2} \mathrm{OH} . \mathrm{HCl}$, pyridine, reflux 4hr. (II) $\mathrm{NH}_{2} \mathrm{CSNHNH}_{2}$, pyridine, reflux 4hr. (III) $\mathrm{NH}_{2} \mathrm{NH}_{2} \cdot \mathrm{H}_{2} \mathrm{O}$, EtOH, reflux 4hr. (IV) $\mathrm{NH}_{2} \mathrm{CONH}_{2}, \mathrm{C}_{2} \mathrm{H}_{5} \mathrm{ONa}$, reflux 5 hr. (V) $\mathrm{NH}_{2} \mathrm{CSNH}_{2}, \mathrm{C}_{2} \mathrm{H}_{5} \mathrm{ONa}$, reflux 5hr. (VI) Acetyl actone, $\mathrm{AcOH}, \mathrm{CH}_{3} \mathrm{COONH}_{4}$, reflux 6hr. (VII) Ethyl aceto acetate, $\mathrm{AcOH}, \mathrm{CH}_{3} \mathrm{COONH}$, reflux $6 \mathrm{hr}$. (xi), $\mathrm{n}=3$, 5,7 mole of propylene oxide (p.o).

\section{Biological Activities}

\subsection{Antitumor Activities}

Doxorubicin was taken as standard as antitumor. Four human tumor cell lines namely, hepatocellular carcinoma (HePG 2), mammary gland (MCF-7), colorectal carcinoma (HCT-116) and Human prostate cancer cell line (PC3) is treated with the synthesized compounds using MTT assay is depicted in table land showed in "figure 8". It was found that pyrazole5 had the most effective potent cytotoxic effect against Human prostate cancer cell line (PC3), hepatocellular carcinoma (HePG-2), colorectal carcinoma (HCT-116) and mammary gland (MCF-7) observed from their IC50 values $5.79,7.81,8.31$ and $8.55 \mu \mathrm{g} / \mathrm{ml}$. Also, pyrazole 4 showed very strong activity against Human prostate cancer cell line (PC3), mammary gland (MCF-7) and strong activity against colorectal carcinoma (HCT-116), hepatocellular carcinoma (HePG-2) observed from their IC50 values 7.67, 9.64, 10.73 and $12.12 \mu \mathrm{g} / \mathrm{ml}$. Compound 7 showed strong activity against mammary gland (MCF-7), colorectal carcinoma (HCT-116) and moderate activity against the two other cell lines. Other compounds showed moderate activity against all cell lines. 
Table 1. Cytotoxic activity of some compounds against human tumor cell.

\begin{tabular}{|c|c|c|c|c|}
\hline \multirow{2}{*}{ Compounds } & \multicolumn{4}{|c|}{ In vitro Cytotoxicity IC50 $(\mu \mathrm{M})$} \\
\hline & HePG2 & MCF-7 & PC3 & HCT-116 \\
\hline DOX • & $4.50 \pm 0.2$ & $4.17 \pm 0.2$ & $8.87 \pm 0.6$ & $5.23 \pm 0.3$ \\
\hline 2 & $83.90 \pm 4.1$ & $61.39 \pm 3.8$ & $93.68 \pm 4.8$ & $85.10 \pm 4.4$ \\
\hline 3 & $72.12 \pm 3.6$ & $37.15 \pm 2.7$ & $46.84 \pm 2.7$ & $66.61 \pm 3.7$ \\
\hline 4 & $12.12 \pm 1.4$ & $9.64 \pm 1.0$ & $7.67 \pm 0.9$ & $10.73 \pm 1.2$ \\
\hline 5 & $7.81 \pm 0.7$ & $8.55 \pm 0.9$ & $5.79 \pm 0.8$ & $8.31 \pm 0.7$ \\
\hline 6 & $42.98 \pm 2.8$ & $54.55 \pm 3.3$ & $58.95 \pm 3.6$ & $33.98 \pm 2.6$ \\
\hline 7 & $24.91 \pm 1.9$ & $14.00 \pm 1.2$ & $22.84 \pm 1.8$ & $14.77 \pm 1.3$ \\
\hline 8 & $54.10 \pm 3.0$ & $78.15 \pm 4.1$ & $66.26 \pm 3.9$ & $49.26 \pm 3.2$ \\
\hline 9 & $31.29 \pm 2.4$ & $39.14 \pm 2.9$ & $16.21 \pm 1.5$ & $26.41 \pm 2.0$ \\
\hline
\end{tabular}

•IC50 ( $\mu \mathrm{M}): 1-10$ (very strong). $11-20$ (strong). $21-50$ (moderate). $51-100$ (weak) and above 100 (non-cytotoxic) • DOX:Doxorubicin

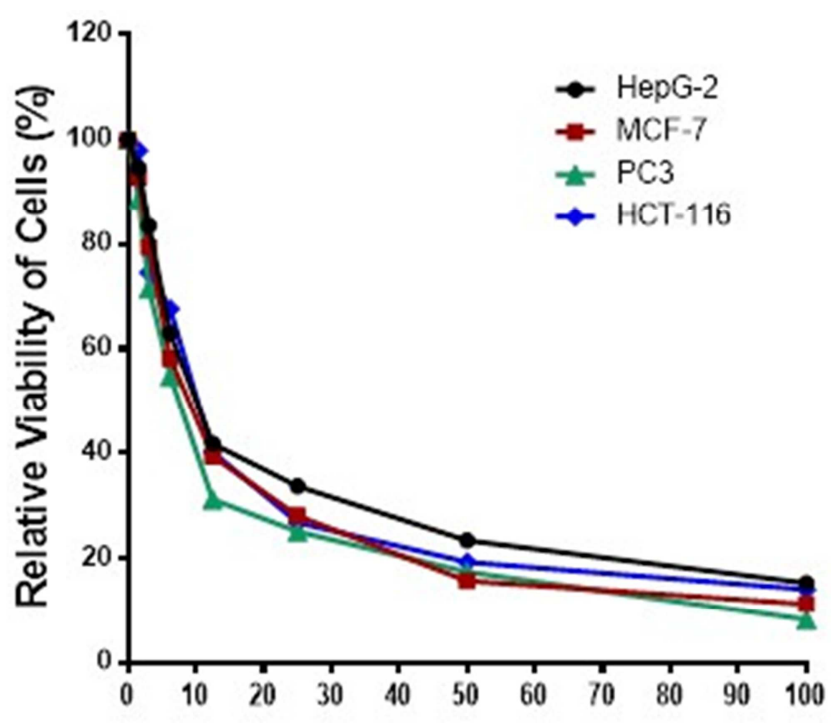

Compound (4)

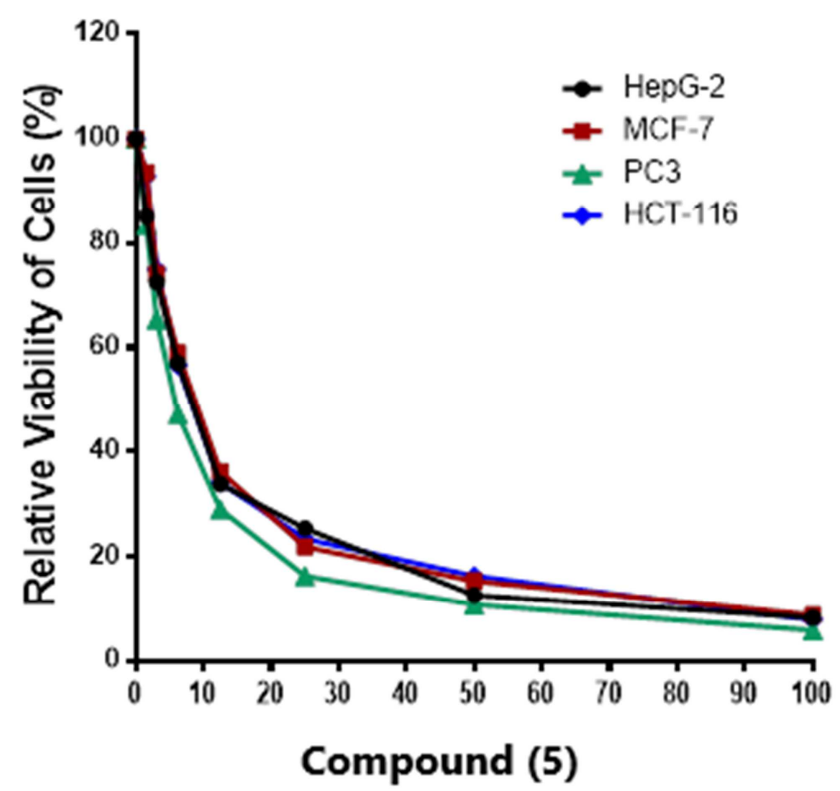

Figure 8. Dose-response effect of the synthesized compound.
Table 2. Antioxidant activity of the synthesized compounds.

\begin{tabular}{lll}
\hline Method & ABTSAbs (control) -Abs (test) /Abs (control) X100 \\
\hline Compounds & Absorbance of samples & \% inhibition \\
\hline Control of ABTS & 0.535 & $0 \%$ \\
Ascorbic-acid & 0.056 & $89.50 \%$ \\
2 & 0.477 & $10.80 \%$ \\
3 & 0.47 & $12.10 \%$ \\
4 & 0.391 & $26.90 \%$ \\
5 & 0.316 & $40.90 \%$ \\
6 & 0.473 & $11.60 \%$ \\
7 & 0.469 & $12.30 \%$ \\
8 & 0.476 & $11.00 \%$ \\
9 & 0.466 & $12.90 \%$ \\
\hline
\end{tabular}

\subsection{Antioxidant Activity}

Ascorbic acid was taken as standard. The ability of the synthesized compounds to prevent oxidation in rat brain and kidney homogenates and their antioxidant activity were evaluated using 2, 2'-and-bis (3-ethylbenzothiazoline-6sulphonic acid) (ABTS) inhibition. From the table 2, compounds, 5, and 4 were showed the most two effective compounds potent antioxidant activities than the other compounds.

\section{Experimental and Methods}

\subsection{Preparation of Nonionic Surfactants from the Synthesized Heterocyclic Compounds}

\subsubsection{Hydroxylation (Propoxylation)}

Following Morgos procedure [22], $0.5 \mathrm{wt} \% \mathrm{KOH}$ solution containing $0.01 \mathrm{~mol}$ of the synthesized compound was stirred and heated to $70^{\circ} \mathrm{C}$ while passing a slow stream of nitrogen through the system to flush out oxygen. The nitrogen stream was stopped and propylene oxide (3,5 and 7 mole) was added dropwise with continuous stirring and heating under an efficient reflux system to retain the propylene oxide. The reaction was conducted at different intervals of time ranging from $1 / 2-1 \mathrm{~h}$. The apparatus was then filled with nitrogen and cooled. The reaction vessel was weighed. The amount of reacted propylene oxide and the average degree of propoxylation were determined from the increment in the mass of the reaction mixture [23]. The selected average 
numbers of moles, n, are 3, 5 and 7 .

\subsubsection{Surface Active Properties of Surfactants \\ Surface and Interfacial Tensions}

Surface and interfacial tension measurements on $2(\mathrm{a}-\mathrm{c})-9$ (a-c) were carried out according to Findlay [24] with aKrüss tensiometer [25] (Krüss GmbH, Hamburg, Instrument Nr. K6) for different concentrations of the synthesized surfactants $(0.05-10-6 \mathrm{~mol} / \mathrm{L})$, using a platinum-iridium ring at constant temperature $\left(25 \pm 1{ }^{\circ} \mathrm{C}\right)$. Paraffin oil was used for the interfacial tension measurements. The tensiometer was calibrated using the method described in ASTM Designation: D1331-01 [26].

\section{Cloud Point}

The cloud point is a measure of the inverse solubility of a nonionic surface active agent. In a temperature-controlled bath, a $1-w t \%$ solution of the tested compound was gradually heated until the clear or nearly clear solution became definitely turbid [27]. The temperature was then recorded and the solution was allowed to cool down until it became clear again. The process was repeated to check the reproducibility of the recorded temperature.

\section{Wetting Time}

Wetting time was measured by immersing a cotton skein (1 $\mathrm{g}$ ) in a $0.1 \mathrm{wt} \%$ solution of the prepared surfactants in distilled water at $25^{\circ} \mathrm{C}$ according to the Draves technique [28]. The sinking time was measured in seconds.

\section{Foaming Properties}

Foam height was measured by the Ross-Miles method [29]. In this procedure a given surfactant solution was allowed to fall from a set height into the same surfactant solution in a volumetric cylinder, hence creating foam. The height of the foam was visually assessed.

\section{Emulsion Stability}

The emulsifying property of the prepared surfactants was determined as follows: In a 100-ml graduated stoppered tube; an aqueous solution of the surfactant $(10 \mathrm{ml}, 20 \mathrm{mmol})$ was mixed with light paraffin oil $(6 \mathrm{ml})$. The mixture was shaken vigorously by magnetic stirring [Thermo scientific Cimarec TM stirring hot plate, model no: sp131320-30, estimated stirring speed $(1,100 \mathrm{rpm})]$ for $2 \mathrm{~min}$ at $25^{\circ} \mathrm{C}$. The tube was placed upright and the separation of the formed emulsion was observed. The time taken for the separation of $(9 \mathrm{ml})$ of the aqueous layer indicates the emulsion stability of the surfactant [30].

\section{Critical Micelle Concentration (CMC) Measurements}

The critical micelle concentration (CMC) is the minimum concentration at which surfactants molecules begin to form micelles [31]. CMC values were obtained through a conventional plot of the surface tension versus the logarithm of the concentration of surfactant. The CMC concentration corresponds to the point where the surfactant first shows the lowest surface tension, and after which the surface tension remains nearly constant.

(Effectiveness) $\pi$ CMC.

The effectiveness of a certain surfactant $\pi_{\mathrm{CMC}}$ is expressed in terms of the decrease in the surface tension that is induced by this surfactant at the critical micelle concentration [32]. It is calculated from the difference between the surface tension of pure water $\left(\gamma_{0}\right)$ and the surface tension of the surfactant solution at the critical micelle concentration $\left(\gamma_{\mathrm{CMC}}\right)$.

$$
\pi_{\mathrm{CMC}}=\gamma_{0}-\gamma_{\mathrm{CMC}}
$$

\section{Efficiency}

The efficiency of a surfactant $\left(\mathrm{PC}_{20}\right)$ is defined by the values of the negative logarithm of the bulk concentration necessary to reduce surface tension by $20 \mathrm{mN} / \mathrm{m}$ [33]. It can be calculated by the following equation, Eq. (2).

$$
\mathrm{PC}_{20}=\frac{\gamma-20-\gamma_{\mathrm{CMC}}}{2.303 \mathrm{nRT}}-\log \mathrm{C}_{\mathrm{CMC}}
$$

Where $\mathrm{R}$ universal gas constant $8.31 \times 107$ ergs $\mathrm{mol}^{-1} \mathrm{~K}^{-1}$. T absolute temperature $\mathrm{K}$

Maximum Surface Excess $\Gamma_{\max }$.

The values of the maximum surface excess $\Gamma$ max expressed in $\mathrm{mol} / \mathrm{cm} 2$ were calculated from surface or interfacial data by the use of Gibbs equation [34] Eq. (3).

$$
\Gamma_{\max }=\frac{-1}{2.303} R T\left(\frac{\delta \gamma}{\delta \log \mathrm{C}}\right)_{T}
$$

Where $\delta \gamma$ surface pressure in $\mathrm{mN} / \mathrm{m}$. C surfactant concentration. $(\delta \gamma / \delta \log C) \mathrm{T}$ is the slope of a plot of surface tension versus concentration curves below $\mathrm{CMC}$ at a constant temperature.

\section{Minimum Surface Area $\left(\mathrm{A}_{\min }\right)$}

Knowing $\Gamma \max$, it is easy to calculate the effective area occupied by each surfactant molecule adsorbed at the air/water interface at surface saturation $[35,36]$. The average area $\mathrm{A}_{\min }$ (in $\AA$. $2 / \mathrm{mol}$ ) is given by Eq. (4).

$$
A_{\min }=10^{16} / \Gamma_{\max } N \text {. }
$$

Where N Avogadro's number $6.023 \times 10^{23}$

\section{Resistance to Hydrolysis}

The resistance of a certain surfactant towards acid and base hydrolysis was established by measuring the surface tension of that surfactant in acidic and alkaline media. Thus, the surface tension of a $0.1 \%$ solution of the surfactant in $5 \%$ sulfuric acid or in $1 \%$ sodium hydroxide was measured at room temperature after boiling for 30 and $60 \mathrm{~min}$.

Biodegradability of the Synthesized Surfactants.

The biodegradation tests of the synthesized nonionic surfactants were performed according to the River Water DieAway method [37]. The river water for testing was sampled from the River Nile. In this test, a stirred solution containing the tested surfactant $(1,000 \mathrm{ppm})$ was incubated at $25^{\circ} \mathrm{C}$.

Samples were withdrawn daily, filtered using Whatman filter paper and the surface tension was measured using a DuNouy tensiometer (Kruss type K6). The process was repeated for 7 days. The biodegradation percentage $\mathrm{D} \%$ was calculated in terms of the measured surface tension according toEq. (5). 


$$
\mathrm{D}=\left[\left(\gamma_{\mathrm{t}}-\gamma_{0}\right) /\left(\gamma_{\mathrm{bt}}-\gamma_{0}\right)\right] \times 100
$$

experiment at time $t$.

Where $\gamma_{\mathrm{t}}$ surface tension at time t. $\gamma_{0}$ surface tension at time zero (initial surface tension). $\gamma_{\text {bt }}$ surface tension of the blank

Table 3. Physicochemical properties of the synthesized surfactants.

\begin{tabular}{|c|c|c|c|c|}
\hline Compound & M.F. & M.wt & Color & Shape \\
\hline $1 \mathrm{a}$ & $\mathrm{C}_{35} \mathrm{H}_{61} \mathrm{NO}_{5}$ & 575 & Yellow & powder \\
\hline $1 b$ & $\mathrm{C}_{41} \mathrm{H}_{73} \mathrm{NO}_{7}$ & 691 & Brown & Semi Solid \\
\hline $1 \mathrm{c}$ & $\mathrm{C}_{47} \mathrm{H}_{85} \mathrm{NO}_{9}$ & 807 & Dark Brown & Semi Solid \\
\hline $2 \mathrm{a}$ & $\mathrm{C}_{42} \mathrm{H}_{65} \mathrm{NO}_{5}$ & 663 & Brown & Semi Solid \\
\hline $2 b$ & $\mathrm{C}_{48} \mathrm{H}_{77} \mathrm{NO}_{7}$ & 779 & Dark Brown & Semi Solid \\
\hline $2 \mathrm{c}$ & $\mathrm{C}_{54} \mathrm{H}_{89} \mathrm{NO}_{9}$ & 895 & BLACK & Semi Solid \\
\hline $3 a$ & $\mathrm{C}_{51} \mathrm{H}_{84} \mathrm{~N}_{2} \mathrm{O}_{8}$ & 852 & Yellow & Powder \\
\hline $3 b$ & $\mathrm{C}_{63} \mathrm{H}_{108} \mathrm{~N}_{2} \mathrm{O}_{12}$ & 1084 & Brown & Powder \\
\hline $3 \mathrm{c}$ & $\mathrm{C}_{75} \mathrm{H}_{132} \mathrm{~N}_{2} \mathrm{O}_{16}$ & 1316 & Dark Brown & Semi Solid \\
\hline $4 a$ & $\mathrm{C}_{52} \mathrm{H}_{86} \mathrm{~N}_{4} \mathrm{O}_{7} \mathrm{~S}$ & 904 & Brown & Powder \\
\hline $4 b$ & $\mathrm{C}_{64} \mathrm{H}_{110} \mathrm{~N}_{4} \mathrm{O}_{11} \mathrm{~S}$ & 1142 & Dark Brown & Semi Solid \\
\hline $4 c$ & $\mathrm{C}_{76} \mathrm{H}_{134} \mathrm{~N}_{4} \mathrm{O}_{15} \mathrm{~S}$ & 1374 & BLACK & Semi Solid \\
\hline $5 \mathrm{a}$ & $\mathrm{C}_{51} \mathrm{H}_{85} \mathrm{~N}_{3} \mathrm{O}_{7}$ & 851 & Yellow & Powder \\
\hline $5 b$ & $\mathrm{C}_{63} \mathrm{H}_{109} \mathrm{~N}_{3} \mathrm{O}_{11}$ & 1083 & Brown & Semi Solid \\
\hline $5 c$ & $\mathrm{C}_{75} \mathrm{H}_{133} \mathrm{~N}_{3} \mathrm{O}_{15}$ & 1315 & Dark Brown & Semi Solid \\
\hline $6 a$ & $\mathrm{C}_{43} \mathrm{H}_{65} \mathrm{~N}_{3} \mathrm{O}_{5}$ & 703 & Yellow & Powder \\
\hline $6 \mathrm{~b}$ & $\mathrm{C}_{49} \mathrm{H}_{77} \mathrm{~N}_{3} \mathrm{O}_{7}$ & 819 & Yellow & Semi Solid \\
\hline $6 c$ & $\mathrm{C}_{55} \mathrm{H} \mathrm{N}_{3} \mathrm{O}_{9}$ & 935 & Brown & Semi Solid \\
\hline $7 \mathrm{a}$ & $\mathrm{C}_{43} \mathrm{H}_{67} \mathrm{~N}_{3} \mathrm{O}_{4} \mathrm{~S}$ & 721 & Yellow & Powder \\
\hline $7 b$ & $\mathrm{C}_{49} \mathrm{H}_{79} \mathrm{~N}_{3} \mathrm{O}_{6} \mathrm{~S}$ & 836 & Yellow & Powder \\
\hline $7 \mathrm{c}$ & $\mathrm{C}_{55} \mathrm{H}_{91} \mathrm{~N}_{3} \mathrm{O}_{8} \mathrm{~S}$ & 953 & Brown & Semi Solid \\
\hline $8 a$ & $\mathrm{C}_{41} \mathrm{H}_{66} \mathrm{~N}_{2} \mathrm{O}_{5}$ & 666 & Yellow & Powder \\
\hline $8 b$ & $\mathrm{C}_{47} \mathrm{H}_{78} \mathrm{~N}_{2} \mathrm{O}_{7}$ & 782 & Brown & Semi Solid \\
\hline $8 c$ & $\mathrm{C}_{53} \mathrm{H}_{90} \mathrm{~N}_{2} \mathrm{O}_{9}$ & 898 & Dark Brown & Semi Solid \\
\hline $9 a$ & $\mathrm{C}_{42} \mathrm{H}_{68} \mathrm{~N}_{2} \mathrm{O}_{5}$ & 678 & Yellow & Powder \\
\hline $9 b$ & $\mathrm{C}_{48} \mathrm{H}_{80} \mathrm{~N}_{2} \mathrm{O}_{7}$ & 796 & Brown & Semi Solid \\
\hline $9 \mathrm{c}$ & $\mathrm{C}_{54} \mathrm{H}_{92} \mathrm{~N}_{2} \mathrm{O}_{9}$ & 912 & BLACK & Semi Solid \\
\hline
\end{tabular}

Table 4. Surface properties of some synthesized surfactants.

\begin{tabular}{|c|c|c|c|c|c|c|c|}
\hline Compound & $\begin{array}{l}\text { No. of } \\
\text { moles }^{\mathrm{a}}\end{array}$ & $\begin{array}{l}\text { Surface tension } \\
(\mathrm{mN} / \mathrm{m}) 0.1 \mathrm{wt} \%\end{array}$ & $\begin{array}{l}\text { Interfacial } \\
\text { tension }(\mathrm{mN} / \mathrm{m}) 0.1 \mathrm{wt} \%\end{array}$ & $\begin{array}{l}\text { Cloud point } \\
\left({ }^{\circ} \mathrm{C}\right) 1.0 \mathrm{wt} \% \\
\end{array}$ & $\begin{array}{l}\text { Wetting time } \\
\text { (s) } 1.0 \mathrm{wt} \%\end{array}$ & $\begin{array}{l}\text { Foam height } \\
(\mathrm{mm}) 1.0 \mathrm{wt} \%\end{array}$ & $\begin{array}{l}\text { Emulsion } \\
\text { stability(min) } 20 \mathrm{~mol}\end{array}$ \\
\hline \multirow{3}{*}{$\begin{array}{l}\text { (a) } \\
2_{(\mathrm{a}-\mathrm{c})}\end{array}$} & 3 & 33 & 10 & 84 & 38 & 80 & 40 \\
\hline & 5 & 34 & 11 & 86 & 40 & 86 & 44 \\
\hline & 7 & 35 & 13 & 96 & 44 & 96 & 46 \\
\hline \multirow{3}{*}{$3_{(\mathrm{a}-\mathrm{c})}$} & 3 & 32 & 12 & 85 & 42 & 85 & 42 \\
\hline & 5 & 34 & 13 & 90 & 44 & 90 & 45 \\
\hline & 7 & 36 & 16 & 110 & 50 & 120 & 52 \\
\hline \multirow{3}{*}{$4_{(\mathrm{a}-\mathrm{c})}$} & 3 & 33 & 11 & 84 & 40 & 84 & 40 \\
\hline & 5 & 34 & 12 & 90 & 45 & 95 & 44 \\
\hline & 7 & 36 & 15 & 100 & 48 & 110 & 47 \\
\hline \multirow{3}{*}{$5_{(\mathrm{a}-\mathrm{c})}$} & 3 & 33 & 11 & 86 & 40 & 85 & 40 \\
\hline & 5 & 35 & 13 & 90 & 44 & 90 & 45 \\
\hline & 7 & 38 & 14 & 95 & 47 & 100 & 48 \\
\hline \multirow{3}{*}{$6_{(a-c)}$} & 3 & 32 & 10 & 82 & 39 & 80 & 38 \\
\hline & 5 & 33 & 12 & 86 & 40 & 90 & 44 \\
\hline & 7 & 36 & 13 & 95 & 45 & 95 & 46. \\
\hline \multirow{3}{*}{$7_{(\mathrm{a}-\mathrm{c})}$} & 3 & 30 & 9 & 80 & 38 & 80 & 38 \\
\hline & 5 & 32 & 11 & 86 & 40 & 86 & 42 \\
\hline & 7 & 36 & 12 & 95 & 42 & 96 & 44 \\
\hline \multirow{3}{*}{$8_{(\mathrm{a}-\mathrm{c})}$} & 3 & 33 & 9.5 & 78 & 37 & 88 & 39 \\
\hline & 5 & 34 & 10 & 85 & 41 & 90 & 42 \\
\hline & 7 & 38 & 11 & 95 & 43 & 99 & 46 \\
\hline \multirow{3}{*}{$9_{(\mathrm{a}-\mathrm{c})}$} & 3 & 32 & 10 & 80 & 38 & 90 & 40 \\
\hline & 5 & 35 & 11.5 & 86 & 42 & 95 & 43 \\
\hline & 7 & 39 & 12 & 96 & 44 & 105 & 48 \\
\hline
\end{tabular}




\begin{tabular}{|c|c|c|c|c|c|c|c|}
\hline Compound & No. of moles ${ }^{a}$ & $\mathrm{CMC}(\mathrm{mmol} / \mathrm{l})$ & $\gamma \mathrm{CMC}(\mathrm{mmol} / \mathrm{l})$ & $\pi \mathrm{CMC} \mathrm{mN} / \mathrm{m}$ & $\mathrm{PC}_{20}(\mathrm{mmol} / \mathrm{l})$ & $\Gamma_{\max }\left(\mathrm{mol} / \mathrm{cm}^{2}\right)$ & $\operatorname{Amin}\left(\AA^{2} / \mathrm{mol}\right)$ \\
\hline \multirow{3}{*}{$\begin{array}{l}\text { (b) } \\
2_{(\mathrm{a}-\mathrm{c})}\end{array}$} & 3 & 5.4 & 32 & 36 & 2.24 & 0.96 & 1.66 \\
\hline & 5 & 7.5 & 35 & 37 & 2.10 & 1.85 & 0.86 \\
\hline & 7 & 10 & 36 & 35 & 1.96 & 2.22 & 0.72 \\
\hline \multirow{3}{*}{$3_{(\mathrm{a}-\mathrm{c})}$} & 3 & 9 & 34 & 37 & 2.00 & 1.85 & 1.96 \\
\hline & 5 & 10 & 35.5 & 35 & 1.98 & 2.00 & 1.25 \\
\hline & 7 & 12 & 37 & 30 & 1.25 & 2.26 & 0.84 \\
\hline \multirow{3}{*}{$4_{(\mathrm{a}-\mathrm{c})}$} & 3 & 11 & 35 & 38 & 2.25 & 0.98 & 1.44 \\
\hline & 5 & 12 & 37 & 34 & 1.85 & 1.25 & 0.76 \\
\hline & 7 & 14 & 39 & 32 & 1.25 & 1.88 & 0.62 \\
\hline \multirow{3}{*}{$5_{(\mathrm{a}-\mathrm{c})}$} & 3 & 10 & 34 & 38 & 1.98 & 1.14 & 2.05 \\
\hline & 5 & 11 & 36 & 35 & 1.23 & 1.56 & 1.08 \\
\hline & 7 & 16 & 38 & 31 & 0.98 & 2.00 & 0.88 \\
\hline \multirow{3}{*}{$6_{(a-c)}$} & 3 & 7.7 & 31 & 35 & 2.61 & 0.78 & 1.70 \\
\hline & 5 & 8.9 & 33 & 33 & 2.25 & 1.59 & 1.76 \\
\hline & 7 & 11 & 35 & 30 & 1.89 & 1.99 & 0.87 \\
\hline \multirow{3}{*}{$7_{(\mathrm{a}-\mathrm{c})}$} & 3 & 5.06 & 30 & 34 & 2.56 & 0.96 & 1.67 \\
\hline & 5 & 7.5 & 33 & 32 & 2.23 & 1.25 & 0.86 \\
\hline & 7 & 10 & 35 & 31 & 1.79 & 1.97 & 0.70 \\
\hline \multirow{3}{*}{$8_{(\mathrm{a}-\mathrm{c})}$} & 3 & 6.5 & 30 & 33 & 1.95 & 0.96 & 1.67 \\
\hline & 5 & 7.8 & 32 & 32 & 1.46 & 1.25 & 0.86 \\
\hline & 7 & 9.5 & 34 & 30 & 0.99 & 1.97 & 0.70 \\
\hline \multirow{3}{*}{$9_{(\mathrm{a}-\mathrm{c})}$} & 3 & 7 & 31 & 34 & 2.10 & 0.96 & 1.67 \\
\hline & 5 & 8.5 & 33 & 31 & 1.62 & 1.25 & 0.86 \\
\hline & 7 & 10.5 & 35 & 30 & 1.25 & 1.97 & 0.70 \\
\hline
\end{tabular}

${ }^{a}$ Number of propylene oxide units

Table 5. Biodegradability of the synthesized surfactants.

\begin{tabular}{|c|c|c|c|c|c|c|c|c|}
\hline Compound & No. of moles a & $1^{\text {st }}$ Day & $2^{\text {nd }}$ Day & $3^{\text {rd }}$ Day & $4^{\text {th }}$ Day & $5^{\text {th }}$ Day & $6^{\text {th }}$ Day & $7^{\text {th }}$ Day \\
\hline \multirow{3}{*}{$2(a-c)$} & 3 & 50 & 61 & 72 & 80 & 92 & - & - \\
\hline & 5 & 42 & 55 & 67 & 77 & 84 & 92 & - \\
\hline & 7 & 40 & 52 & 66 & 75 & 82 & 90 & - \\
\hline \multirow{3}{*}{$3(a-c)$} & 3 & 44 & 59 & 65 & 79 & 85 & 92 & - \\
\hline & 5 & 42 & 58 & 62 & 80 & 89 & 90 & - \\
\hline & 7 & 46 & 55 & 60 & 78 & 88 & 92 & - \\
\hline \multirow{3}{*}{$4(a-c)$} & 3 & 53 & 66 & 76 & 89 & 90 & 93 & - \\
\hline & 5 & 50 & 60 & 74 & 87 & 92 & - & - \\
\hline & 7 & 48 & 52 & 66 & 74 & 88 & 92 & - \\
\hline \multirow{3}{*}{$5(a-c)$} & 3 & 56 & 63 & 76 & 84 & 96 & 100 & - \\
\hline & 5 & 52 & 62 & 75 & 82 & 92 & 98 & - \\
\hline & 7 & 50 & 60 & 72 & 80 & 90 & 92 & - \\
\hline \multirow{3}{*}{$6(a-c)$} & 3 & 50 & 67 & 77 & 88 & 92 & 93 & - \\
\hline & 5 & 46 & 65 & 78 & 86 & 90 & 92 & - \\
\hline & 7 & 40 & 55 & 67 & 78 & 80 & 95 & - \\
\hline \multirow{3}{*}{$7(a-c)$} & 3 & 54 & 69 & 78 & 87 & 92 & - & - \\
\hline & 5 & 46 & 68 & 75 & 89 & 90 & 93 & - \\
\hline & 7 & 41 & 56 & 67 & 85 & 92 & 95 & - \\
\hline \multirow{3}{*}{$8(a-c)$} & 3 & 50 & 66 & 77 & 89 & 90 & 93 & - \\
\hline & 5 & 44 & 62 & 73 & 85 & 92 & 94 & - \\
\hline & 7 & 40 & 56 & 65 & 81 & 90 & 92 & - \\
\hline \multirow{3}{*}{$9(\mathrm{a}-\mathrm{c})$} & 3 & 52 & 68 & 77 & 88 & 92 & 96 & - \\
\hline & 5 & 46 & 64 & 76 & 84 & 90 & 93 & - \\
\hline & 7 & 41 & 58 & 64 & 80 & 90 & 92 & - \\
\hline
\end{tabular}

${ }^{\mathrm{a}}$ Number of propylene oxide units 
Table 6. Resistance of the synthesized surfactants towards acidic and alkaline hydrolysis.

\begin{tabular}{|c|c|c|c|c|c|c|c|}
\hline \multirow{3}{*}{ Compound } & \multirow{3}{*}{$\begin{array}{l}\text { Surface tension } \\
(\mathrm{mN} / \mathrm{m}) 0.1 \mathrm{wt} \%\end{array}$} & \multicolumn{6}{|c|}{ Surface tension (mN/m) $0.1 \%$ surfactant (stability to hydrolysis) } \\
\hline & & \multirow{2}{*}{$\mathrm{H}_{2} \mathrm{SO}_{4}(5 \%) 25^{\circ} \mathrm{C}$} & \multicolumn{2}{|c|}{ After boiling $(5 \%) \mathrm{H}_{2} \mathrm{SO}_{4}$} & \multirow{2}{*}{$\begin{array}{l}\mathrm{NaOH}(1 \%) \\
25^{\circ} \mathrm{C}\end{array}$} & \multicolumn{2}{|c|}{ After boilingNaOH (1\%) } \\
\hline & & & $30 \mathrm{~min}$ & $60 \mathrm{~min}$ & & 30 min & $60 \mathrm{~min}$ \\
\hline $2 \mathrm{a}$ & 33 & 33 & 35 & 36 & 33 & 33 & 33 \\
\hline $2 \mathrm{~b}$ & 34 & 34 & 35 & 36 & 34 & 33 & 33 \\
\hline $2 \mathrm{c}$ & 35 & 34 & 36 & 37 & 35 & 33 & 34 \\
\hline $3 \mathrm{a}$ & 32 & 32 & 34 & 35 & 32 & 32 & 33 \\
\hline $3 \mathrm{~b}$ & 34 & 35 & 36 & 37 & 34 & 34 & 35 \\
\hline $3 \mathrm{c}$ & 38 & 36 & 37 & 38 & 38 & 36 & 37 \\
\hline $4 \mathrm{a}$ & 33 & 34 & 36 & 37 & 33 & 34 & 34 \\
\hline $4 \mathrm{~b}$ & 35 & 35 & 36 & 38 & 35 & 33 & 34 \\
\hline $4 \mathrm{c}$ & 38 & 38 & 39 & 40 & 38 & 37 & 38 \\
\hline $5 \mathrm{a}$ & 33 & 33 & 34 & 35 & 33 & 33 & 33 \\
\hline $5 \mathrm{~b}$ & 35 & 34 & 35 & 36 & 35 & 32 & 33 \\
\hline $5 \mathrm{c}$ & 39 & 38 & 39 & 40 & 39 & 37 & 38 \\
\hline $6 \mathrm{a}$ & 32 & 34 & 35 & 37 & 32 & 33 & 34 \\
\hline $6 \mathrm{c}$ & 36 & 36 & 36 & 37 & 36 & 34 & 35 \\
\hline $7 \mathrm{a}$ & 30 & 35 & 36 & 36 & 30 & 33 & 34 \\
\hline $7 \mathrm{~b}$ & 32 & 36 & 37 & 38 & 32 & 34 & 34 \\
\hline $7 \mathrm{c}$ & 36 & 37 & 38 & 39 & 36 & 35 & 35 \\
\hline $8 \mathrm{a}$ & 33 & 32 & 33 & 34 & 33 & 34 & 34 \\
\hline $8 \mathrm{~b}$ & 34 & 33 & 34 & 35 & 34 & 32 & 33 \\
\hline $8 \mathrm{c}$ & 38 & 35 & 36 & 37 & 38 & 34 & 34 \\
\hline $9 \mathrm{a}$ & 32 & 33 & 34 & 35 & 32 & 33 & 33 \\
\hline $9 \mathrm{~b}$ & 35 & 34 & 35 & 36 & 35 & 33 & 34 \\
\hline $9 \mathrm{c}$ & 39 & 36 & 37 & 39 & 39 & 34 & 35 \\
\hline
\end{tabular}

\subsection{Experimental}

\subsubsection{Synthesis of N- (4-acetyl Phenyl) Stearamide (1)}

A solution of stearoyl chloride $(0.01 \mathrm{~mol})$ and $\mathrm{p}$ aminoacetophenone $(0.01 \mathrm{~mol})$ in $(20 \mathrm{~mL})$ dry acetone was refluxed for $1 \mathrm{~h}$. The reaction mixture was concentrated, cooled, and the produced solid was filtered off and recrystallized from ethanol. Compound 1 was obtained as a pale yellow powder in $80 \%$ yield, mp90-92 ${ }^{\circ} \mathrm{C}$, IR (KBr): $03342(\mathrm{NH}), 2918$ (aliphatic), 1675, $1661(2 \mathrm{C}=\mathrm{O}) \mathrm{cm}^{-}$ ${ }^{1} .{ }^{1} \mathrm{H}$ NMR (DMSOd6): $\delta{ }^{\mathrm{s}} 10.05(\mathrm{~s}, 1 \mathrm{H}, \mathrm{NH}), 7.75-8.07(\mathrm{~m}$, $4 \mathrm{H}, \mathrm{ArCH}), 2.5\left(\mathrm{~s}, 3 \mathrm{H}, \mathrm{CH}_{3} \mathrm{C}=\mathrm{O}\right), 1.23\left(\mathrm{~m}, 32 \mathrm{H}, 16 \mathrm{CH}_{2}\right)$, $0.88\left(\mathrm{t}, 3 \mathrm{H}, \mathrm{CH}_{3}\right)$.

MSm/z (\%):401 ( $\dot{\mathrm{M}}+, 0.16), 387$ (0.03), 359 (0.05), 268 (0.08), 64 (100).

Anal. Calc. (\%) for $\mathrm{C} 26 \mathrm{H} 43 \mathrm{NO} 2: \mathrm{C} ; 77.75, \mathrm{H} ; 10.79, \mathrm{~N}$; 3.49. Found $\mathrm{C} ; 77.66, \mathrm{H} ; 10.69, \mathrm{~N} ; 3.38$.

\subsubsection{Synthesis of N-(4-(3- phenylacryloyl) Phenyl) Stearamide (2)}

A mixture of Compound $1(0.01 \mathrm{~mol})$ and benzaldehyde $(0.01 \mathrm{~mol})$ was fused on sand bath for $1 / 2 \mathrm{~h}$. The reaction mixture was cooled. The produced solid was dried and recrystallized from ethanol. Compound 2 was obtained as dark brown powder in $95 \%$ yield, mp96-98 ${ }^{\circ} \mathrm{C}$, IR (KBR):v3330 (NH), 2918 (CHaliphatic), 3050 (CHaromatic), 1671, $1680(2 \mathrm{C}=\mathrm{O}) \mathrm{cm}^{-1} .{ }^{1} \mathrm{HNMR}$ (DMSOd6): $\delta^{\prime} \mathrm{s}_{10.05}(\mathrm{~s}$, $1 \mathrm{H}, \mathrm{NH}), 7.80-7.50(\mathrm{~m}, 9 \mathrm{H}, \mathrm{Ar}-\mathrm{H}), 1.23\left(\mathrm{~m}, 32 \mathrm{H}, 16 \mathrm{CH}_{2}\right)$, $0.88\left(\mathrm{t}, 3 \mathrm{H}, \mathrm{CH}_{3}\right) . \mathrm{MSm} / \mathrm{z}(\%): 490(\dot{\mathrm{M}}+1,0.08), 488$ (0.06), 412 (0.06), 387 (0.08), 268 (0.14) 64 (100).

Anal. Calc. (\%) for C33H47NO2: C; 80.93, H; 9.67, N;
2.86. Found C; 80.90, H; 9.66, N; 2.83.

\subsubsection{Synthesis of N-(4-(3-phenyl-2, 3-dihydroisoxazol-5- yl) N Phenyl) Stearamide (3)}

Equimolar quantities of Compound $2(0.01 \mathrm{~mol})$ and hydroxylaminehydrochloride $(0.01 \mathrm{~mol})$ in pyridine $(5 \mathrm{ml})$ was boiled for $4 \mathrm{~h}$. The reaction mixture was cooled and then poured onto ice and HClwhile stirring. The produced solid was filtered off and recrystallized from ethanol. Compound 3 was obtained as yellow powder in $90 \%$ yield, mp $110-112^{\circ} \mathrm{C}$, IR (KBR):v3415 (NH' $\left.{ }^{\mathrm{s}}\right), 3067$ (CHaromatic), 2918 (CHaliphatic), $1665(\mathrm{C}=\mathrm{O}) \mathrm{cm}^{-1}$.

${ }^{1}$ HNMR (DMSOd6): $\delta$ 's10.05 (s, 1H, NHamide), 8.89 (s, $1 \mathrm{H},=$ CHoxazole $), 2.3(\mathrm{~s}, 1 \mathrm{H}, \mathrm{NH}$ oxazole $), 8.51(\mathrm{~s}, 1 \mathrm{H}, \mathrm{H}-$ 3oxazole), 8.01-7.57 (m, 9H, $\mathrm{ArCH}), 1.23$ (m, 32H, 16 $\mathrm{CH}_{2}$ ), $\left(0.83 \mathrm{t}, 3 \mathrm{H}, \mathrm{CH}_{3}\right)$.

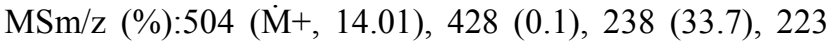
(26.23), $131(100)$

Anal. Calc. (\%) for C33H48N2O2: C; 78.53, H;9.59, N; 5.55. Found C; 78.47, H; 9.52, N; 5.49

\subsubsection{Synthesis of N-(4-(1-carbamothioyl-5-phenyl-4, 5-dihydro-1H-pyrazol-3-yl) Phenyl) Stearamide (4)}

Reaction of Compound $2(0.01 \quad \mathrm{~mol})$ with thiosemicarbazide $(0.01 \mathrm{~mol})$ in pyridine $(5 \mathrm{ml})$ was heated for $4 \mathrm{~h}$. The reaction mixture was cooled and then poured onto ice and $\mathrm{HCl}$ while stirring. The produced solid was filtered off and recrystallized from ethanol. Compound 4 was obtained as ayellow powder in $95 \%$ yield, mp $140-142^{\circ} \mathrm{C}$, IR (KBr):v3423 $\left(\mathrm{NH}^{,}\right.$), 2919 (CHaliphatic), $1661(\mathrm{C}=\mathrm{O}),, 1176$ $(\mathrm{C}=\mathrm{S}) \mathrm{cm}^{-1}$

${ }^{1}$ HNMR (DMSOd6): $\delta$ 's 10.4 (s, 1H, NHamide), 10.27 (s, 
2H, $\left.\mathrm{NH}_{2}\right), 7.9,7.2(\mathrm{~m}, 9 \mathrm{H}, \mathrm{ArCH}), 2.5(\mathrm{t}, 1 \mathrm{H}, \mathrm{CHpyrazole})$, 2.3 (d, $2 \mathrm{H}, \mathrm{CH}_{2}$ pyrazole), $1.23\left(\mathrm{~m}, 32 \mathrm{H}, 16 \mathrm{CH}_{2}\right), 0.84(\mathrm{t}, 3 \mathrm{H}$, $\left.\mathrm{CH}_{3}\right) . \mathrm{MSm} / \mathrm{z}(\%): 563(\mathrm{M}+1,1.9), 490(1.4), 486(0.3), 296$ (0.6), 281 (6.6), 235 (100).

Anal. Calc. (\%) for C34H50N4OS: C; 72.55, H; 8.95, N;9.95. Found: C; 72.49, H; 8.86, N; 9.89.

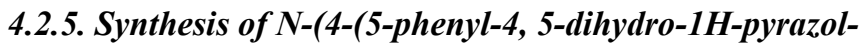 3-yl) Phenyl) Stearamide (5)}

Reaction of Compound $2(0.01 \mathrm{~mol})$ and hydrazine hydrate $(0.01 \mathrm{~mol})$ in ethanol $(20 \mathrm{ml})$ was heated under reflux for $4 \mathrm{~h}$. The reaction mixture was cooled and then poured onto ice and $\mathrm{HCl}$ while stirring. The produced solid was filtered off and recrystallized from ethanol. Compound 5 was obtained as ayellow powder in $85 \%$ yield, mp90-92 ${ }^{\circ} \mathrm{C}$, IR (KBr):v3324 (NH, s), $3035 \quad$ (CHaromatic), 2918 (CHaliphatic), $1661 \quad(\mathrm{C}=\mathrm{O}), \quad 1597 \quad(\mathrm{C}=\mathrm{N}) \quad \mathrm{cm}^{-1} .{ }^{1} \mathrm{HNMR}$ (DMSOd6): $\quad \delta^{\prime} \mathrm{s}_{10.2} \quad$ (s, 1H, NHamide), $9.9 \quad(\mathrm{~s}, 1 \mathrm{H}$, NHpyrazole), 7.83-7.08 (m, 9H, ArCH), 2.5 (t, 1H, CHpyrazole), 2.3 (d, 2H, $\mathrm{CH}_{2}$ pyrazole), $1.23(\mathrm{~m}, 32 \mathrm{H}$, $\left.16 \mathrm{CH}_{2}\right), 0.84\left(\mathrm{t}, 3 \mathrm{H}, \mathrm{CH}_{3}\right) . \mathrm{MSm} / \mathrm{z}(\%): 503(\dot{\mathrm{M}}+1,34.63)$, 426 (0.9), 237 (100).

Anal. Calc. (\%) for C34H49N3O: C; 78.68, H; 9.80, N; 8.34. Found C; 78.59, H; 9.70, N; 8.29.

\subsubsection{Synthesis of $\mathrm{N}$-(4-(2-hydroxy-6-phenyl pyrimidine-4- yl) Phenyl) Stearamide (6)}

Equimolar amounts of Compound $2(0.01 \mathrm{~mol})$ and urea $(0.01 \mathrm{~mol})$ in the presence of sodium ethoxide $(0.01 \mathrm{~mol})$ was refluxed for $5 \mathrm{~h}$. The reaction mixture was cooled and then poured onto ice and $\mathrm{HCl}$ while stirring. The produced solid was filtered off and recrystallized from ethanol. Compound 6 was obtained as ayellow powder in $80 \%$ yield, mp $94-96^{\circ} \mathrm{C}$, IR (KBr):v3417 (OH), 3318 (NH), 3054 (CHaromatic), 2917 (CHaliphatic), $1668(\mathrm{C}=\mathrm{O}), 1603 \quad(\mathrm{C}=\mathrm{N}) \quad \mathrm{cm}^{-1} .{ }^{1} \mathrm{HNMR}$ (DMSOd6): $\delta^{\prime} \mathrm{s} 10.27$ (s, 1H, OH), 10.2 (s, 1H, NHamide), 8.01-7.7 (m, 9H, ArCH), $7.5(\mathrm{~s}, 1 \mathrm{H},=$ CHpyrimidine $), 1.23$ $\left(\mathrm{m}, 32 \mathrm{H}, 16 \mathrm{CH}_{2}\right), 0.84\left(\mathrm{t}, 3 \mathrm{H}, \mathrm{CH}_{3}\right)$.

MSm/z (\%):529 (M+, 1.1), 501 (1.40), 453 (0.9), 263 (5.3), 248 (3.2), 223 (100)

Anal. Calc. (\%) for C34H47N3O2: C; 77.09, H; 8.94, $\mathrm{N} ; 7.93$. Found: C; 77.00, H; 8.86, N; 7.89.

\subsubsection{Synthesis of N-(4-(2-mercapto-6-phenylpyrimidin-4- yl) Phenyl) Stearamide (7)}

Reaction of Compound $2(0.01 \mathrm{~mol})$ with thiourea $(0.01$ mol) in the presence of sodium ethoxide $(0.01 \mathrm{~mol})$ was refluxed for $5 \mathrm{~h}$. The reaction mixture was cooled and then poured onto ice and $\mathrm{HCl}$ while stirring. The produced solid was filtered off and recrystallized from ethanol. Compound 7 was obtained as ayellow powder in $85 \%$ yield, mp100 $102^{\circ} \mathrm{C}, \mathrm{R}$ (KBr):v3331 (NH), 3055 (CHaromatic), 2918 (CHaliphatic), $2591(\mathrm{SH}), 1668(\mathrm{C}=\mathrm{O}), 1600(\mathrm{C}=\mathrm{N}) \mathrm{cm}^{-1}$. ${ }^{1} \mathrm{HNMR}$ (DMSOd6): $\delta^{\text {'s } 10.17}$ (s, 1H, SH), $10.2(\mathrm{~s}, 1 \mathrm{H}$, NHamide $), 8.92-7.2(\mathrm{~m}, 9 \mathrm{H}, \mathrm{ArCH}), 7.0(\mathrm{t}, 1 \mathrm{H}$, $=$ CHpyrimidine $), 1.45\left(\mathrm{~m}, 32 \mathrm{H}, 16 \mathrm{CH}_{2}\right), 0.82\left(\mathrm{t}, 3 \mathrm{H}, \mathrm{CH}_{3}\right)$. MSm/z (\%):545 (M+1, 5.6), 469 (4.2), 279 (100), 264 (7.1).

Anal. Calc. (\%) for C34H47N3OS: C; 74.82, H;8.68,
N;7.70. Found: C; 74.76, H; 8.60, N;7.64.

\subsubsection{Synthesis of N-(4-(6-acetylpyridin-2-yl) Phenyl) Stearamide (8)}

Reaction of Compound $2(0.01 \mathrm{~mol})$ with acetyl acetone $(0.01 \mathrm{~mol})$ in $\mathrm{AcoH}$, in the presence of ammonium acetate and reflux for $5 \mathrm{~h}$ produce compound 8 after coolingand poured onto ice while stirring. The produced solid was filtered off and recrystallized from ethanol. Compound 8 was obtained as ayellow powder in $83 \%$ yield, mp80- $82^{\circ} \mathrm{C}$, IR (KBr):v3357 (NH), 3032 (CHaromatic), 2917 (CHaliphatic), 1699, $1600(2 \mathrm{C}=\mathrm{O}), 1530(\mathrm{C}=\mathrm{N}) \mathrm{cm}^{-}$ ${ }^{1}$.1HNMR (DMSOd6): $\delta^{\prime} \mathrm{S} 10.2(\mathrm{~s}, 1 \mathrm{H}, \mathrm{NH}), 8.2-7.41(\mathrm{~m}, 7 \mathrm{H}$, ArCH), 2.5 (t, 2H, $\left.\mathrm{CH}_{2} \mathrm{CO}\right), 2.1\left(\mathrm{~s}, 3 \mathrm{H}, \mathrm{CH}_{3} \mathrm{CO}\right), 1.3(\mathrm{~m}$, $\left.30 \mathrm{H}, 15 \mathrm{CH}_{2}\right), 0.82\left(\mathrm{t}, 3 \mathrm{H}, \mathrm{CH}_{3}\right) . \mathrm{MSm} / \mathrm{z}(\%): 479(\dot{\mathrm{M}}+1+$, 0.06), 464 (0.06), 212 (0.19), 120 (100).

Anal. Calc (\%) for C31H46N2O2: C; 77.78, H;9.69, $\mathrm{N} ; 5.85$, Found: C; 77.69, H; 9.58, N;5.76.

\subsubsection{Synthesis of N-(4-(6-propionylpyridin-2-yl) Phenyl) Stearamide (9)}

Reaction of Compound $2(0.01 \mathrm{~mol})$ with ethylacetoacetate $(0.01 \mathrm{~mol})$ in $\mathrm{AcOH}$, in the presence of ammonium acetateand heating for $5 \mathrm{~h}$. The reaction mixture was cooled and then poured onto ice while stirring. The produced solid was filtered off and recrystallized from ethanol. Compound 9 was obtained as ayellow powder in $89 \%$ yield, mp84- $86^{\circ} \mathrm{C}$, IR (KBr):v3415 (NH), 3032 (CHaromatic), 2917 (CHaliphatic), 1700, $1600 \quad(2 \mathrm{C}=\mathrm{O}), \quad 1529 \quad(\mathrm{C}=\mathrm{N}) \quad \mathrm{cm}^{-1} . \quad{ }^{1} \mathrm{HNMR}$ (DMSOd6): $\delta$ 's 10.2 (s, 1H, NH), 8. 2-7.45 (m, 7H, ArCH), 3.4 (q, $\left.2 \mathrm{H}, \mathrm{CH}_{3} \mathrm{CH}_{2} \mathrm{CO}\right), 2.5\left(\mathrm{t}, 2 \mathrm{H}, \mathrm{CH}_{2} \mathrm{CO}\right), \delta 0.96(\mathrm{t}, 3 \mathrm{H}$, $\left.\mathrm{CH}_{3} \mathrm{CH}_{2} \mathrm{CO}\right), 1.3\left(\mathrm{~m}, 30 \mathrm{H}, 15 \mathrm{CH}_{2}\right), 0.82\left(\mathrm{t}, 3 \mathrm{H}, \mathrm{CH}_{3}\right)$.

MSm/z (\%):492 (M+, 0.926), 478 (0.63), 464 (2.2), 226 (1.47), 91 (100).

Anal. Calc. (\%) for $\mathrm{C}_{32} \mathrm{H}_{48} \mathrm{~N}_{2} \mathrm{O}_{2}: \mathrm{C} ; 78.00, \mathrm{H} ; 9.82, \mathrm{~N}$; 5.69. Found: $\mathrm{C} ; 77.90, \mathrm{H} ; 9.75, \mathrm{~N} ; 5.60$.

\section{Conclusion}

Some new synthesized compounds can be used as anticancer, antioxidant especially compounds 4 and 5 and also can be used in industrial uses such as a wetting agent in textile manufacture.

\section{References}

[1] Abdelmajeid, A., Amine, M. S. and Hassan, R. A. (2017) Fatty Acids in Heterocyclic Synthesis. Part XVI Synthesis of NonIonic Surfactants Containing Piperidine, Piperazine, Imidazole Based on Thiadiazole and Evaluation of the Microbiological Activities. International Journal of Organic Chemistry, 7, 346368. https://doi.org/10.4236/ijoc.2017.74029.

[2] Iman A. G. Karim, Mahasen S. Amine, Amal A. Mahmoud, Alaa S. Gouda. J. Surfact. Deterg. (2014) 17:509-523. Fatty acids in heterocyclic synthesis. Part XIV; synthesis of surface active agents from some novel class of oxadiazole, thiadiazole and triazole derivatives having microbiological activities. 
[3] Amine, M. S., Eissa, A. M. F., Elsawy, A. A, Shaaban, A. F., El said, R. Grasas Aceites. (2004) New heterocycles having a double character as antimicrobial and surface active agents. Part1: nonionic compounds from fatty acid isothiocyanate. 55, 370-376.

[4] Amine, M. S., Mahmoud, A. A., Badr, S. K., Gouda, A. S. (2011) Fatty acids in heterocyclic synthesis. Part XIII: 2chloro-5-heptadecyl[1, 3, 4] thiadiazole as a building block for the synthesis of S-triazolo[2, 4-b]thiadiazole, benzimidazo[2, 1-b]thiadiazole, thiadiazolo[2, 3-b]quinazolin-5-one as well as thiadiazol-2-yl (piperidine, pyridazine and/or phthalazine) Olaj, Szappan, Kozmetika, 60, 51-57.

[5] Amine, M. S., Mahmoud, A. A., Badr, S. K., Gouda, A. S. (2013) Fatty Acids in Heterocyclic Synthesis. Part XI: Facile and Convenient Routes to Synthesize Eco-friendly Polyfunctionalized Thiadiazoles, Triazole, Thiadiazolo [3, 2a] pyrimidines and Imidazo[2, 1-b]thiadiazole for Pharmaceutical and Industrial Purposes. Egypt. J. Chem. 56 (5), 379-401.

[6] Amine, M. S., Mahmoud, A. A., Badr, S. K., Gouda, A. S. (2012) Fatty acids in heterocyclic synthesis part xii: synthesis of surfactants from pyrazole, isoxazole, pyrimidine, and triazine, incorporating the 1,3,4-thiadiazole moiety having dyeing and antimicrobial activities J. Surf. Deterg. 15, 179190.

[7] Amine, M. S., Ahmed, M. H. M., Hebash, K. A., and ElSheikh, A. A. (2010) Utilization of stearic in heterocyclic synthesis Part 8: synthesis of some new thiadiazoles and triazoles of industrial application. Olaj, Szappan, Kozmetika, 59, 30-34.

[8] Amine, M. S., Ahmed, M. H. M., Hebash, K. A., El-Sheikh, A. A. (2007) New heterocycles having a double character as antimicrobial and surface active agents. Part 6: novel thiadiazole from stearic acid. OLAJ, Szappan, Kozmetika, 56, 57-61.

[9] Hanahan, D. and J. Folkman. (1996). Patterns and emerging mechanisms of the angiogenic switch during tumorigenesis. Cell 86: 353-364.

[10] Sumitani, K., R. Kamijo, T. Toyoshima, Y. Nakanishi, K. Takizawa, M. Hatori, and M. Nagumo. (2001). Specific inhibition of cyclooxygenase-2 results in inhibition of proliferation of oral cancer cell lines via suppression of prostaglandin E2 production. Journal of Oral Pathology \& Medicine 30: 41-47.

[11] Ding, X. Z., C. A. Kuszynski, T. H. El-Metwally, and T. E. Adrian. (1999). Lipoxygenase inhibition induced apoptosis, morphological changes, and carbonic anhydrase expression in human pancreatic cancer cells. Biochemical and biophysical ResearchCommunications 266: 392-399.

[12] Ding, X. Z., W. G. Tong, and T. E. Adrian. (2001). 12lipoxygenase metabolite12 (S) HETE stimulates human pancreatic cancer cell proliferation via protein tyrosine phosphorylation and ERK activation. International J. of Cancer J. International Du Cancer 94: 630-636.

[13] Form, D. M., and R. Auerbach. (1983). PGE2 and angiogenesis, F. et al. (2009) The discovery of the potent Aurora inhibitor M. Proceedings of the Society for Experimental Biology and Medicine 172: 214-218.

[14] Chahrour, O., Cairns, D., Omran, Z. (2012) Small molecule kinase inhibitors as anti-cancer therapeutics. Mini-Rev. Med.
Chem. 5, 399-411.

[15] Bebbington, D., Binch, H., Charrier, J.-D., Everitt, S., Fraysse, D., Golec, J., Kay, D., Knegtel, R., Mak, C., Mazzei K-0457 (VX-680). Bioorg. Med. Chem. Lett. 19, 3586-3592.

[16] Fletcher, G. C., Brokx, R. D., Denny, T. A., Hembrough, T. A., Plum, S. M., Fogler, W. E., Sidor, C. F., Bray, M. R. (2011) ENMD-2076 is an orally active kinase inhibitor with antiangiogenic and antiproliferative mechanisms of action. Mol. Cancer Ther. 1, 126-137.

[17] Mortlock, A. A., Foote, K. M., Heron, N. M., Jung, F. H., Pasquet, G., Lohmann, J. J., Warin, N., Renaud, F., de Savi, C., Roberts, N. J., et al (2007) Discovery, synthesis, and in vivo activity of a new class of pyrazoloquinazolines as selective inhibitors of Aurora B kinase. J. Med. Chem. 9, 2213-2224.

[18] Kumar A, Sinha S, Chauhan PM. (2012) Synthesis of novel antimycobacterial combinatorial libraries of structural diverse substituted pyrimidines by three-component solid phase reactions. Bioorg Med Chem Lett.12, 667-669.

[19] Baraldi, P. G, Pavani, M. G, Nunez, M, et al. (2002) Antimicrobial and antitumor activity of N-heteroimine-1, 2, 3dithiazole and their transformation in triazole- imidazo- and pyrazolopyrimidines. Bioorg Med Chem. 10, 449-456.

[20] Hanan, E. J., Fucini, R. V., Romanowski, M. J., Elling, R. A., Lew, W., Purkey, H. E., Vanderporten, E. C., and Yang, W. (2008). Design and synthesis of 2-amino-isoxazolopyridines as Polo-like kinase inhibitors. Bioorg. Med. Chem. Lett. 18, 5186-5189.

[21] Mohamed, S. F., Youssef, M. M., Amr, A. E., Kotb, E. R. (2008). Antimicrobial activities of some synthesized pyridines, oxazines, and thiazoles from 3-aryl-1- (2-naphthyl) prop-2-en-1-ones. Sci. Pharm. 76:279-303.

[22] Morgos J, Sallay P, Farkas L, Rusznak I (1983) A novel way for ethoxylation with the basic catalyst. J Am Oil Chem Soc 60:1905-1907.

[23] Ahmed M. H. M, Sallay P, Rusznak I, Farkas L (1996) Determination of the average ethoxylation degree. Tenside Surf Deterg 33:410-411.

[24] Findlay A (1963) Practical physical chemistry, 6th edn. Longmans, London, pp 1040-1069.

[25] Weil JK, Stirton AJ, Nunez-Ponzoa MV (1966) Ether alcohol sulfates. The effect of oxypropylation and oxybutylation on surface active properties. J Am Oil Soc 43:603-609.

[26] ASTM D1331-01 (2001) Standard Test method for surface and interfacial tension of solutions of surface active agents.

[27] Durham K (1961) Properties of detergent solutionsamphipathyand adsorption, vol 1. Surf Activity Deterg. MacMillan \&Co. Ltd., London, pp 1-28.

[28] Draves CZ, Clarkson R (1931) A new method for the evaluation of wetting agents. J Am Dye Stuff Report 20:201.

[29] Ross J, Milles GD (1941) Apparatus for comparison of foaming properties of soaps and detergents. Oil Soap 18:99102.

[30] Scholnick F, Linfield WM (1977) Lactose-derived surfactants (III): fatty esters of oxyalkylated lactitol. J Am Oil Chem Soc 54:430-435. 
[31] Colwell CE, Rixon WE (1961) Consideration in the use of nonionicsurface-active agents. Am Dyest Re 50:679-682.

[32] Lu JR, Lee EM, Thomas RK, Penfold J, Flitsch SL (1993) Direct determination by neutron reflection of the structure of triethylene oxide monododecyl ether layers at the air/water interface. Langmuir 9:1352-1358.

[33] Matsuoka K, Moroi Y (2003) Micellization of fluorinated amphiphiles. Curr Opin Colloids Interface Sci 8:227-234.

[34] Zhigang Xu, Li Pengfei, Qi Weihong, Li Zongshi, Lubo Ch (2006) Effect of aromatic ring in the alkyl chain on surface properties of aryl alkyl surfactant solution. J Surf Deterg 9:245-248.
[35] Karakashev SI, Nguyen AV, Miller JD (2008) Equilibrium adsorption of surfactants at the gas-liquid interface. Adv Polymer Sci 218:25-55.

[36] Karakashev SI, Manev ED (2002) Effect of interactions betweenthe adsorbed species on the properties of single and mixed surfactantmonolayers at air/water interface. J Colloid Interface Sci 248:477-486.

[37] Falbe J (1986) Surfactants for consumer, Chap 4. Springer Verlag, Heidelberg. 